\title{
Challenges for Urban Housing Development for Improving Livelihoods and Well-being of Population of Low-Income Group in Tanzania: The Case of Dar es Salaam
}

\author{
Juma Kiduanga
}

jkiduanga@udsm.ac.tz

\begin{abstract}
Development of housing is essential source of improved livelihoods and well-being of rapid population growth. Data collected from a sample population of 186 respondents and that gathered through documentary analysis revealed that urban housing in Dar es Salaam is facing a challenge in accumulation for the population to improve their livelihood and well-being. The challenge is attributed to low capability level of the population in taping financial resource from micro institutions to expand housing. The conclusion made in the paper is enhancing capability of the population in accessing finance form micro institutions is crucial for them to expand housing which is the main source for improving their livelihood and well-being. The following are suggested to enhance the capability of the population: There is a need to provide training to the population on the use of the NGOs to get housing finance and also encourage them to become members of SACCOS. These will enable to access finance from the institutions another policy consideration is that there is a need for the officials of the finance institutions to visit the population in order to identify their needs related to housing improvement. Also there is a need to raise accountability in institutions involved in supplying water, electricity and land so as the population can acquire the facilities adequately as part in the housing development.
\end{abstract}

Keywords: urban housing, low-income population, livelihood

\section{Introduction}

High fertility of less developed countries like Uganda Livelihood when improved is an important factor in cities such as Dar es Salaam to meet the expanding needs of rapid urban population growth. The situation enables the population to increase their well-being. Housing fulfills a number of functions of livelihood which contributes to the well-being of the population. The improved livelihood and rising of the well-being of the rapid population growth in Dar es Salaam is contributed by housing when it develops implying that it becomes adequate as it is sustainably expanding both quantitative and qualitative terms to meet the requirements of increasing population. Such improved livelihood attained by the population as a result of housing development is in a number of dimensions. These include among others generation of employment and income opportunities realized when the population use housing to get locations for engaging in activities. The outcome will lead to the establishment of households in social context. According to Mahanga (2002 p.2I) quoting Ermisch (1990) such process in a particular geographical area can take place in three main ways:

(i) They can alter the number and composition of family units in an area's population by influencing marriage, divorce and childbearing patterns; (ii) They can change an area's population by Affecting migration into and from the area;

(iii) they can influence the probability that unmarried adults and family units form a separate household.

The clarification of adequate housing concept has been provided by the Committee on Economic, Social and Cultural Rights, of the United Nations by using the following 7 criteria as indicated in UNHabitat (2005, 20-2I):

I. Legal security of tenure;

2. Availability of services, materials, facilities and infrastructure. The items included in this element essentially for housing to become adequate are water supply, sanitation systems and garbage collection, electricity supply systems, road networks, rain water drainage systems and street lighting;

3. Affordability - the issue of housing to become expensive to the occupants has to be avoided;

4. Habitability which is explained by enough space and protection from cold, damp, heat, rain, wind or other threats to health, structural hazards and disease as well as absence of overcrowding;

5. Accessibility - adequate housing must be accessible to all members of the community without segregation on the basis of gender, income or vulnerability 
6. Location - the housing location should be in an area which allows access to employment options, health-care services, schools, child-care centers and other social facilities. It should not be built on polluted sites or sites liable to hazards such as flooding, landslides etc.

7. Cultural adequacy - housing must also be culturally adequate.

Such understanding of adequate housing leaves behind the volume of output as another component of housing development. In the situation of city experiencing rapid population growth, the volume of output has to expand for housing resource to be seen as increased livelihood to satisfy the raising well-being of the growing population.

In Dar es Salaam, the bulk of housing developed in the context of rapid urbanization affected by population growth is inadequacy and its ability to be used for effective livelihood means to raise the wellbeing of low-income population has been low. The provision of housing intended to such income group forming large part of the population in the city, is poor in quality and quantity despite the variety of efforts made. The situation is shown by a number of indicators. For instance, housing is mainly provided in unplanned/informal/squatter settlements which are insecure. In urban areas settlements of such type are still growing despite the efforts made. The settlements have increased number of houses sheltering large population of low-income category (Kiduanga, 2014). In 2002 housing in the settlements was resided by $70 \%$ of total population in the city while, in other urban areas the population accounted for $60 \%$ (The World Bank AF TU I\&2, 2002). By 2010 out of housing units built in the cities and towns between $60 \%$ and $70 \%$ were in the unplanned settlements with $80 \%$ recorded in Dar es Salaam (PMO-RALG, 20II and UN-Habitat, 20I0). Many houses are in slum condition with inadequate safe water, sanitation and other infrastructure and insecure residential status as well as overcrowded making occupants of the houses being subject to poverty. The trend of such kind of housing has been increasing as the city expands spatially to integrate rural areas to become part of Dar es Salaam. The housing output developed in the city fails to expand to match with the growth of low-income population. One of the indicators of this situation is the high level of housing occupancy rate. According to the Basic Demographic and Socio-Economic Profile Report it was found that $50 \%$ of households in Dar es Salaam in 2014 had one room used for sleeping (URT, 20I4). The average household size in the city in the year was 4 members (Dar es Salaam Region Socio-Economic Profile, 20I4).
Given the above evidence, the fact is that the urban housing is facing challenges in its development as a result it is unable to satisfy the improved livelihood and the well-being required by the growing population of low-income in the city. The paper intends to examine the challenges facing urban housing development and the stumbling block to the low-income population in improving their livelihood and well-being by using the developed urban housing.

The paper is organized into six sections. After the introduction provided in section one, the literature review and theoretical framework are discussed in section two. The methodology is explained in section three while section four deals with the presentation and analysis of the results. The discussion is in section five. The conclusion and policy consideration are presented in section six.

\section{Literature Review and Theoretical Framework Literature Review}

Concerning the challenges facing urban housing in its development and the way it is unable to meet the improved livelihood and well-being of the lowincome population, the issue is being reviewed by stating the factors for inability of the low-income population to develop adequate housing for improving their livelihood and well-being. Many studies have cited barriers in accessing the housing resources by low-income population (Mutero, 2009; Makalle et al; 2009; Wakely \& Riley, 20II; Sheuya, 2004). The resources are building materials, land and finance. The studies argue that when the population accesses the resources, they are able to improve the condition of housing they occupy. It is argued that the inaccessibility of the resources is attributed to a variety of factors. There are those noted by poverty facing the population (Makalle et al; 2009). Other studies have found weakness of institutional framework (Kool et al; 1989) which impedes land supply and finance for the low-income population to acquire for constructing better/adequate housing. Building materials are cited by other studies to be the major cause for the failure of low-income population to have better housing. They are expensive in the market resulting into pushing up housing construction costs and decent housing become inaccessible by the low-income population (PMO-RALG, 20II). Studies citing surveyed building plots and credit facilities, have noted that though they are important in ensuring tenure security and better quality of housing respectively, they are not easily obtained by lowincome population due to lack of appropriate policies, strategies and incapability of the institutional framework (Koo et al; 1989; Blasi, 2005; Muteso, 
2010). The studies however are salient in explaining factors responsible for weakness of the policies and strategies and inability of the institutional framework. The central argument on the challenges of housing development is associated to capability level embedded to the low-income population. Very few studies have looked at this issue. Capability is essential for the population to improve housing condition to become productively used for increasing their livelihood and well-being. The capability is defined as knowledge, skills, know-how and endowed health possessed by the population. When the people acquire capability they are able not only to access the resources for acquisition of better housing but also to make use of it for improving their livelihood and well-being. It can be enhanced through various strategies implemented in the society.

\section{Theoretical Framework}

Major important issues being examined are concerning population in improving livelihood and well-being through housing afflicted with challenges caused by a number of underpinning forces. The focus is therefore on the people being satisfied by livelihood achieved from housing. For this reason, theoretical approach of Sustainable Livelihood is applied to provide direction in the examination of the issues because the approach pays much attention to the issues of people-centered. According to Ellis (2006: 347) the approach is strong in recognizing or discovering:

(a) the multiple and diverse character of the livelihoods;

(b) the prevalence of the institutionalized blockages to improving livelihoods;

(c) the social as well as economic character of livelihood strategies;

(d) the principal factors implicated in rising or diminishing vulnerability; and

(e) the micro-macro (or macro-micro) links that connect livelihoods to policies.

Livelihood concept according to Chambers and Conway (1992) quoted in Scoones (1998) is embedded by elements such as capabilities, resources and activities. In addition, strategies, institutional process and organizational structure are essential elements for livelihood to become a means of living (Krantz, 200I). Housing, livelihoods and well-being are three concepts related to each other. While the well-being revolves around a variety of progressive values, the population and the city are striving to achieve for better live in urban setting; or the process of transforming the socio-economic and political aspects of urban population to the progressive level; such level of attainment can be realized by adequate housing as a strong livelihood means. Each variable of the Sustainable Livelihood Approach (See Figure 3.I) is performing important functions in developing livelihood. The variable of assets category like physical, human, financial, natural and social are essential because livelihood development for productive use according to (Majale, 2003) takes place on the basis of the assets which the populations involved have to access within a broader socio-economic and physical contexts. In the case of development of housing, the process is conditioned by types of assets like finance, land, labour and building materials. Within the socioeconomic and physical contexts, there are emerging forces which affect negatively the livelihood driving the population to the side of poverty. Housing is not static; sometimes it is underpinned by forces regressing the property to state of dilapidated. The capability of the population as another element of livelihood apart from playing role in protecting housing against vulnerability-shocks and stresses to be sustainable in meeting various ends; it also enables the population to increase their livelihood through expanding the owned housing resource.

The variable of livelihood strategies according to Majale (2003) are influenced by transforming structures and processes namely, policies, laws, policies, cultures and the institutions and processes which in turn have bearing on livelihood outcomes (i.e. the achievements or outputs of livelihood strategies). 


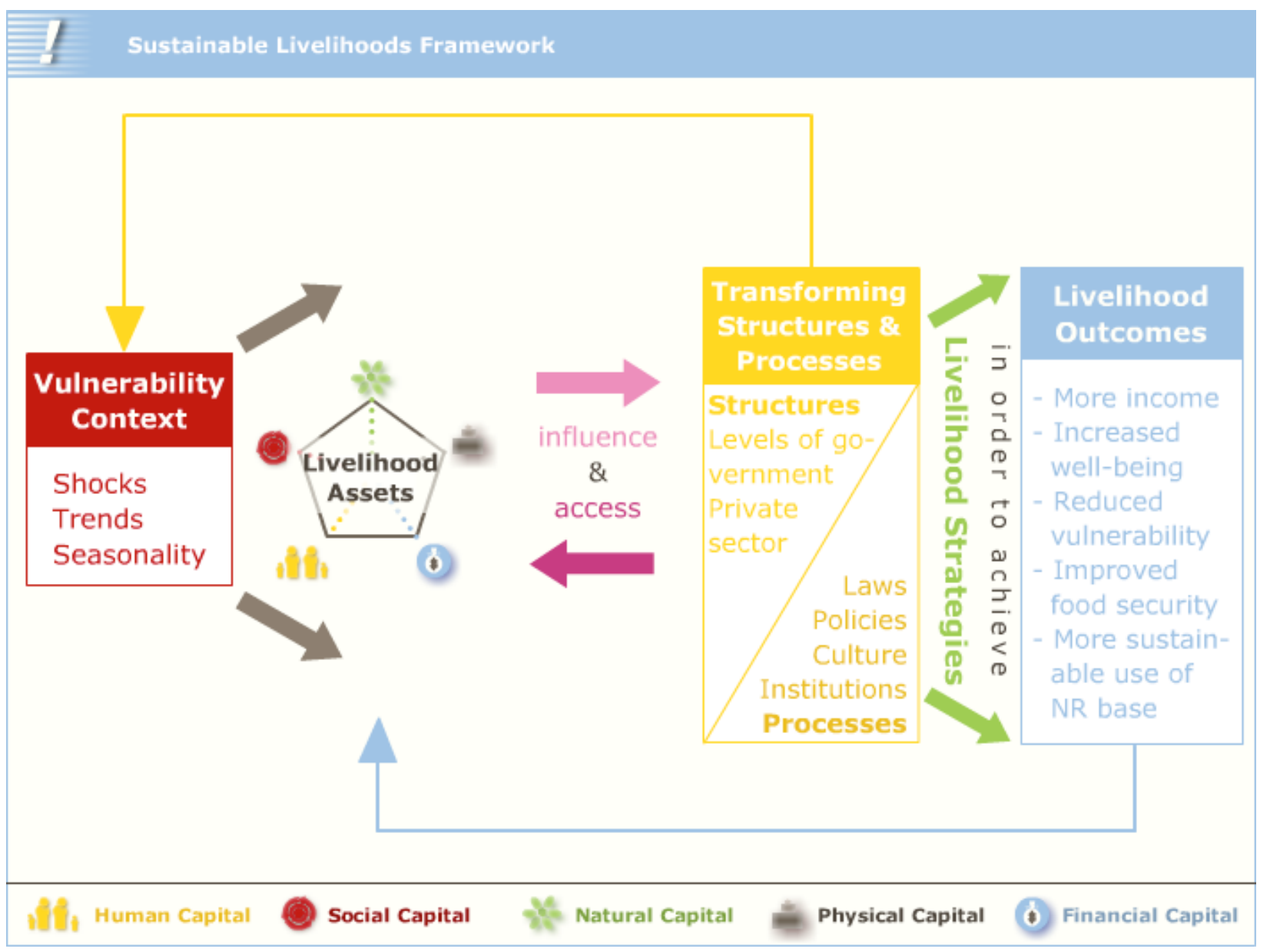

Figure 3.I Sustainable Livelihoods Framework

Source; DFID (2000): Sustainable Livelihoods Guidance Sheets.

Department for International Development.

http://www.livelihoods.org/info/info_guidancesheets.html (accessed: 4-8-20I6)

\section{Methodology}

Research Design

The plan for undertaking this study of urban housing in relation to livelihoods and well-being of the population in the city consisted of a number of components which are explained as follows:

\section{Research Approach}

This was a descriptive study which made the researcher to employ survey approach for collecting data of different variables at one time. The data collected were both qualitative and quantitative. The data of this nature were essential to be collected in order to meet the formulated objectives of the study and they were gathered through both qualitative and quantitative methods.

\section{Study Area}

The study was conducted in the city of Dar es Salaam from June to July, 2015. The city-region of Dar es Salaam maintains the status quo of being a primate city of Tanzania despite the initiatives undertaken by the government since 197I to make Dodoma the capital city of Tanzania. The city has the highest concentration of industries in the country. Other socio-economic activities being developed in Dar es Salaam include activities of education, transport, trade, commerce, communication, health and water. It is the country's chief port, connected by a network of roads, railways and waterways not only to rest of the country, but also to neighbouring countries of Kenya, Uganda, Rwanda, Burundi, Zambia, Malawi and Democratic Republic of Congo (DRC). All the socio-economic establishments available act as a factor contributing to increase in population of Dar es Salaam. According to 2012 Population and Housing Census, the population of the city was 4,364,54I with annual growth rate of 5.6 percent (Dar es Salaam Region Socio-Economic Profile, 2014). The proportion of inadequate houses was estimated at $80 \%$ out of 500,000 housing units available in the city. The city-region of Dar es Salaam is divided into three municipalities of Kinondoni, Ilala, and Temeke. 


\section{Study Population}

According to Babbie (1992) the target population is the population about which a researcher is interested in gaining information and drawing conclusion from. The target population for the study was the household members engaging in various activities using housing and officials involved in housing development policy in the city. Given the fact that the researcher was not able to study the entire population, a plan was made to collect information from the sample population as follows:

\section{Sample Size and Sampling Procedures}

A sample size of 186 respondents was selected. Out of this number, 180 were heads of households while 6 were officials drawn from municipal and lowincome settlement levels. The selection of the officials was done purposive considering the officials who are responsible for housing development policy and strategies.

In the city from the 3 municipalities available Buguruni low-income settlement in llala, Kawe lowincome settlement in Kinondoni and Tandika lowincome settlement in Temeke were selected. The heads of households were drawn from each of the three low-income as follows: 60 from Buguruni, while from each low-income of Kawe and Tandika 60 heads of households were selected. All the three low-income settlements were purposively selected on the basis of having many households of lowincome category engaging their activities in the houses. The choice of the study settlements was done after discussion with the municipal officials. In each low-income settlement, 30 inadequate rented houses were drawn for conducting interviews to the head of landlord households and head of tenant households in each house. To avoid bias of house selection, every 'nth' rented house in the settlement was chosen to get the head of landlords and head of tenants for interviewing. The first rented house was selected at random. The interval number ' $n$ ' was arrived at by dividing the number of houses available in the settlement by a sample size of 30 rented houses occupied by landlords and tenants. Where the 'nth' house was not for renting purpose i.e. owneroccupier house, a church, a school, a mosque or any other house serving other purposes, then a substitute either $(n-I)$ th or $(n+I)$ th rented house was selected.

\section{Data Collection Methods}

\section{Secondary Data Collection Methods}

Secondary data were collected through critical analysis of various policies, legislations, strategies and by-laws, as well as concepts and theories relating to the theme was undertaken to identify the gaps and collect secondary data. These materials were http://aps.journals.ac.za available in the Government documents, research reports, and books, journals accessed in the University of Dar es Salaam and Ardhi University Libraries as well as in the Websites.

\section{Primary Data Collection Methods}

Primary data were collected through the following methods:

\section{Face to Face Interview}

Face to face interviews were conducted with either head of household or spouse to each rented house visited. Both husband and wife make decision in the engagement and distribution of livelihood activities for contributing to the well-being of the households. Semi-structured questionnaire was used as instrument when the interviews were conducted to gather data from household heads. Information from the three municipal officials was collected through indepth interview using interview guide.

\section{Observation}

Observation method was applied to collect qualitative information during conducting the interviews with the head of households. The information collected was on the conditions of the rented houses and some of livelihood activities carried out in the houses. Observation focused on whether or not the house is complete, the floor is cemented, quality of windows, doors, availability of water, leakages, cracks. This method was also used to identify the low-income rented house in order to reach the low-income household for interviewing.

\section{Focus Group Discussion (FGD)}

One focus group discussion was held participated by the three officials of the three low-income settlements. The issue brought for the discussion was on the strategies for improving the livelihoods activities carried out by the population of low-income category.

\section{Data Analysis}

A computer was used to enter the data collected. They were analysed using the method of simple descriptive statistics such as percentages and presented in tables. The programme used to process and analyse the data was the Statistical Package for Social Sciences (SPSS).

\section{Ethical Consideration}

A clearance was issued by the Office of Vice Chancellor, University of Dar es Salaam for undertaking the research. The clearance was addressed to the Dar es Salaam Regional Administrative Officer for allowing researcher to 
conduct the research in the city. A letter from the office of Regional Administrative was sent to the three Municipal Directors introducing the researcher and the research assistant for involving in the work in their municipalities.

We introduced ourselves and explained the households the purpose of conducting research which is to get data from the community in order to solve problems by revising the policies related to improving housing and the livelihoods. Respondents were assured of their anonymity and getting feedbacks as they participated freely in improving the housing and livelihood policies and strategies aimed at raising their well-being.

\section{Limitation of the Study}

The study confined only to Dar es Salaam in three low-income settlements of the three municipalities of Ilala, Kinondoni and Temeke. Due to financial and time limitation, it was not possible for the study to cover other cities and towns in Tanzania.

\section{Presentation, Analysis of the Results \\ Presentation and Analysis of the Findings \\ Housing Development}

Housing development is important for the population to acquire the livelihood resource in the city. Majority of the respondents $(67.7 \%)$ developed housing by way of construction which started in 2002. The process was conditioned by mobilization of finance which made the respondents to purchase land, building materials and hired labour. During house construction, there was a division of labour as organization form which involved craftsmen who were hired to build a house by the house owner. Organization, supervision, supply of building materials and negotiation of labour charge with the craftsmen who have skills of house construction were under the responsibility of the house owner. It is worth noting that such, tasks to be under the responsibility of the house owner are essential for knowing the value of the developed livelihood.

Finance as important input for housing construction was mobilized out of savings of incomes obtained after the household heads worked in the formal sectors as artisans, traders, lawyers, army officers, procurement officers, land surveyors, community development officers, craftsmen, doctors, nurses, accountants, teachers at college level, registrars and laboratory technicians. Results showed head of households were engaged in skilled occupations which enabled them to mobilize housing finance from the received incomes. TZS of $10,000.00$ was the average daily income of the respondents after engaging in the skilled occupations. The secondary and post secondary education created an important foundation for the respondents $(81.7 \%)$ to undergo training for achieving the different skills.

The completion level as one aspect of housing development is important to know because it influences usage of the asset as livelihood means by the households in the city for well-being achievement. The data of housing completion is presented in Table I as follows:

Table I: House Completion

\begin{tabular}{|l|l|}
\hline Response & Per cent \\
\hline Yes & 81.2 \\
\hline No & 18.8 \\
\hline Total & 100 \\
\hline
\end{tabular}

Source: Fieldwork conducted in Dar es Salaam City from June to July, 2015

Table I present's data obtained from the study areas which indicate that majority of the respondents $(81.2 \%)$ managed to complete their houses. The observation made on the physical structure of completed houses indicated they were permanent type and conformed to the standard set by the urban authority because they had walls built of cement/sand blocks, roofs covered with corrugated iron sheets and stable ceilings, doors and windows. The floors of the houses were cemented. The following facilities were found to be available in the houses: electricity, water,kitchen and pit latrine as toilet facilities used by the occupants.

\section{The Practice of Renting Business}

Housing has made possible renting business to be practiced by the majority of respondents $(96 \%)$ in the three city's municipalities. The business in the city is associated with urban development resulted by population growth as the major factor. As Panel (1975) points out, any discussion of developing countries and their cities' development should begin with understanding of population growth. Panel emphasizes this point because as it has been shown by a number of scholars, there is a relationship between population and urbanization process. The population trends of the city have gone through various periods of relatively rapid population growth with less than 200,000 people between 1910 up to late 1960s. From 1967 to 1978 the population had grown from 273,000 to over 850,000 (Berry, et al

http://aps.journals.ac.za 
1982). Within ten years period, from 1978 the city's population reached 1.5 million in 1988 and increased to 2.2 million in 1992 (Mlozi, 1997). It has been reported that the residents in the city were 2,487,288 by 2002 (Dar es Salaam Region SocioEconomic Profile, 2014). According to 2012 Population and Housing Census reported the population of the city in 2012 was $4,928,923$ people with population average annual growth rate of $4.8 \%$ from 2002 to 2012 (URT, 20I3). The population of the city has influenced both the supply and demand for rented housing.

\section{Supply and Demand for Rented Housing}

House-owners are motivated to supply rented housing in order to generate incomes. The Municipal Authorities of llala and Temeke also benefit from the incomes by collecting property tax from $50 \%$ of houses constructed in each of the municipality. It is unfortunate that in Kinondoni the collection of property tax is not undertaken in many rented houses resided by the population of low-income category. While in Ilala and Temeke municipalities majority of house-owners $(56.5 \%$ and $62.5 \%$ respectively) charge monthly rent per room between TZS $20,000 /-$ and $50,000 /-$ in Kinondoni monthly rent per room is above TZS $50,000 /-$. The renting is a recent phenomenon, in percentages $24.7 \%$ started the period of $|99|-200 \mid$ while $41.7 \%$ commenced between 2002-20II and 25.8\% started after 201 I. House-owners-tenant relationship is one of the factors affecting stability of the livelihood defined by rented housing. $86.0 \%$ of the respondents expressed good relation on condition that both house-owner and tenant fulfill their obligations. The obligations are timely payment of rents; the two parties show respect, compliance of rules and regulations by the two parties. Literature shows that major responsibilities to be performed by landlords in order to create good relation with tenants in the course of tenancy agreement include maintenance of physical states of rental housing; responding tenants' complaints; having communication with tenants in case there is rent rise and giving notice in case of eviction of tenants takes place. Obligations supposed to be fulfilled by tenants include prompt rents payment; cleanliness of properties and use the housing as it has been agreed for (Gilbert and others, 1997; Hoffman and others, 1991 and Kabyemera, 2000). These issues were reported to be dominant sources of conflict occurring between landlord and tenant. Findings reported by Amis (1988) quoted in UNCHS (1990 pp.6) indicate that in Kibera landlordtenant relations center on monthly rent payment. In Lagos, tenants get upset when landlords do not repair the accommodation and fail to respond to http://aps.journals.ac.za their complaints. Few tenants believe that their landlords look after the houses properly (Aika, 1990 pp 96 quoted in UNCHS, 1993 pp.83). Tenants who form the large proportion of city's population demand housing for accommodation and spaces to undertake their businesses such as hotels, shops and stationeries. Tenants with the following personal and socio-economic characteristics create demand for rental housing: In terms of age tenants who demand rental housing are younger than their landlords. $73.6 \%$ of them are under 38 years old while $16.4 \%$ of tenants are above 38 years old. Tenants of both sexes demand renting. Majority of them $86.3 \%$ are males while females constituted $14.7 \%$. The marital status of tenants' findings revealed that nearly three quarters $74.0 \%$ are married, while unmarried tenants constituted $26.0 \%$. Of these, single are the majority tenants $56.4 \%$ while $21.8 \%$ tenants are divorced separated and widow tenants constitute $14.1 \%$ and $7.7 \%$ respectively. Among the 44 single tenants, 27 are men while 17 are women. These findings imply that there are more single male than single female tenants who demand rental housing owned by landlords in sample areas. This suggests that male tenants take longer time to get married than female tenants. Most male tenants cited economic difficulty coupled with small space they had for accommodation as the reasons why they take longer time to get married.

The level of formal education acquired by tenants in sample areas was low. The proportion of tenants completed primary education of standard $1-8$ is $88 \%$ while $11 \%$ completed adult education. Tenants completed secondary education of the level of form I -6 is $8.2 \%$ and few tenants (1.9\%) acquired post secondary education of certificate, or diploma or degree levels.

Rural migrant tenants in study areas are common. $84.4 \%$ migrated to Dar es Salaam from rural areas without livings in any urban centres while those migrated from towns constitute $15.1 \%$. The composition of male children under 18 years in tenants' households, the study found $45.5 \%$ of them compose of no male children under 18 years while $52.5 \%$ compose of I-3 male children, $2.0 \%$ tenants' households compose of 4- 6 male children. Thus, households composed of I-3 male children are the dominant with a substantial proportion of households compose of no male children. Regarding composition of female children less than 18 years in households, findings revealed that majority of households $(52.2 \%)$ compose of I-3 female children with a substantial proportion of households (46.5\%) compose of no female children and $1.3 \%$ of the households compose of 4-6 female children. Composition of male adults in households, the study revealed, 
households $75.6 \%$ of households have one male adult of the above 18 years old, 47 while $15.7 \%$ of the households have no male adults, $0.7 \%$ of the households have 3 male adults and $1.0 \%$ has 4 or more male adults. Thus, households' compositions of one male adult are dominant. As far as households composition of female adults of the age above 18 years is concerned, findings from survey areas showed that out of households $(70.2 \%)$ households compose of one female adult while $14.0 \%$ of the households compose of no female adults, $10.4 \%$ of them with 2 female adults, 13 households (4.4\%) with 3 female adults and 3 households (1.0\%) composed of 4 or more female adults. This implies that households with one female adult were dominant. On the basis of the above information, the composition of tenant households in sample areas was of the feature one female, one male adult of the age above 18 years old.

The challenges for urban housing development and its inability to satisfy improved livelihood and well-being of the low-income population

Housing for the population of low-income category forming majority of residents in the city is of renting tenure. The challenge facing the rented housing tenure was of two types. The complete rented house showed that its development was limited to accumulate/expand to generate another housing unit or extend rooms to the available housing unity.
The incomplete housing was another type of challenge reported by $18.8 \%$ of the respondents. Majority of respondents (63.0\%) possessing both complete and incomplete housing let between I and 3 rooms of the housing while two rooms were occupied by themselves. These characteristic features define subsistence type of urban housing. Findings indicated that low capability level of the population owning housing in taping the financial opportunities from various institutions established in the city was the major cause of the challenge. The presence of subsistence urban housing, held back the population in increasing livelihoods for meeting their needs. Table 2 presents the livelihoods and wellbeing denied by the house owners as a result of failure of housing expansion. Generation of sustainable income as form of improved livelihood was denied by majority of respondents (57.4\%) due to failure to expand their housing hence inability to increase their living standard. $24.5 \%$ of the respondents reported that they were unable to generate income for more investments.

Tenants' respondents revealed problems of housing presented in Table 3 as stumbling block in increasing their livelihoods and well-being. Smallness of rooms and lack of modern toilets were the major problems of housing reported by tenants (40.5\%) and $(30.5 \%)$ respectively.

Table 2: Percentage of House Owners Responded on Denied Improved Livelihoods and Well-being

\begin{tabular}{|l|c|}
\hline Form of Denied Livelihood and Well-being & \% of Responses \\
\hline Reliable source of extra income & 13.8 \\
\hline Generate income for further investments & 24.5 \\
\hline $\begin{array}{l}\text { Sustainable income generation for improving the living standard and } \\
\text { meeting daily and education needs }\end{array}$ & 57.4 \\
\hline Obtaining more money for paying property tax other necessary fees & 4.3 \\
\hline Total & 100 \\
\hline
\end{tabular}

Source: Fieldwork conducted in Dar es Salaam City from June to July, 2015

Table 3: Percentage of Tenants Facing Problems in the Occupied Housing

\begin{tabular}{|l|l|}
\hline Types of housing problem & $\%$ of Responses \\
\hline Irregular rise in rents & 12.0 \\
\hline Smallness of rooms & 40.5 \\
\hline $\begin{array}{l}\text { Introduction of harsh regulations by house owners like time of tenants to } \\
\text { be inside the compound }\end{array}$ & 10.5 \\
\hline Floods & 6.5 \\
\hline Lack of modern toilets-flush/push or ventilated improved pit toilets & 30.3 \\
\hline Total & 100 \\
\hline
\end{tabular}

Source: Fieldwork conducted in Dar es Salaam City from June to July, 2015 


\section{Discussion}

Housing has been an important source of livelihood. There are a number of livelihood types provided by housing to the population for their well-being achievement. When rented housing is developed in the city, both tenant and non-tenant populations benefit from it in a number of ways. For instance, the benefit can be in the form of getting accommodation which is common among low-income populations who form many residents in many fast growing cities of Africa. Statistics indicated in 2014 about $70 \%$ of Dar es Salaam city's residents were accommodated in the rented housing while in Arusha city $60 \%$ of the population lived in rented housing (Mlawa, 20I5). In addition Kiusi (2013) has noted that the significance contribution of rented housing is the provision of a place for undertaking informal activities which are the major source of livelihood to $60 \%$ of the city's population.

The capability of the population is essential for housing expansion/accumulation from subsistence to sustainable level to cope with the increasing demands as a result of population growth. In Dar es Salaam like in other cities of Third World the population has been growing rapidly mainly due to rural-urban migrants. According to Dar es Salaam Region SocioEconomic Profile, 2014 large part of the population migrating is formed by the youths moving from rural areas of Tanzania to the city attracted by a number of better livelihoods like industrial, commercial and those obtained from the informal sectors, all of them is argued to be undertaken in housing. High level of capability is required by the population to get finance as resource for housing accumulation. Finance has been central of all other resources for housing development; evidence revealed in a variety of forms by a number of housing studies. For instance, Makalle et all (2006) in a study done in Dodoma, Capital City of Tanzania found that the construction and improvement of housing in the city is severely restricted by access to credit in order to get finance. Despite finance is central, it has been a challenge in the cities and towns of Africa which takes place in a number of forms. Afrane et all (2014) found two forms of finance challenge facing the middle and lowincome population in urban areas of Ghana for housing development. These were scarcity of longterm housing finance and the excessive cost of available formal financing sources. The form of finance challenge found in this study differs from that reaveled by Afrane and others. It was low capability level of the population to tape the available financial resources from the institutions for owning addition housing units for improving their livelihoods and those of tenants. The one housing unit possessed is argued to be useful to the population because it http://aps.journals.ac.za constitutes a base in development process rather than not having. A report by UN-HABITAT of 2010 has assessed the same value when the household own one house. It is pointed out that it is basically the essence of the livelihood approach.

In Tanzania since 1991 there has been development of financial sector which has become more liberalized with mushrooming of institutions of a variety of sizes-micro, medium and large operating in a competitive and flexible manner to cater financial loans to the population for meeting their various livelihoods such as housing acquisition and others. Development in the sector has taken place through both legislative and non legislative measures put in place by the Government. The legislative measures are such as the Banking and Financial Institutions Act of 1991 and the Mortgage Financing Act of 2008. Hanai and Chambi (2009) have found that the National Microfinance Law passed in 2005 provided a legal foundation for the establishment of micro financial institutions like Savings and Credit Cooperative Societies (SACCOSs) and NonGovernment Organizations (NGOs) in Tanzania to diversify their functions to include mobilizing savings and issuing loans to members. Such development led a significant amount of raised capital in the country for microfinance (ibid...) and provide opportunities for the low income population to borrow and utilize it in improving their housing as reliable source of livelihood.. Indeed such microfinance institutions are better suited than the traditional institutions for the population particularly of low income to get housing finance. The traditional institutions have a number of stiff conditions and unaffordable by the low-income earners because they charge high interest rates on mortgage lending (between $16 \%$ and 19\%). Also a borrower for housing finance is required to deposit 10\% of the total value of the house which according to Hanai and Chambe (2009) is unaffordable and holding back people wishing to acquire housing units.

\section{Conclusion and Policy considerations}

The capability of population owning urban housing in Dar es Salaam is at low level resulting failure to tape the financial resources from the institutions of small scale to expand housing for improving livelihoods and wellbeing of the population. There is a need to provide training to the population on the use of the NGOs to get housing finance and also encourage them to become members of SACCOS. These will enable to access finance from the institutions another policy consideration is that there is a need for the officials of the finance institutions to visit the population in order to identify their needs related to housing improvement. Also there is a need to raise 
accountability in institutions involved in supplying water, electricity and land so as the population can acquire the facilities adequately as part in the housing development.

\section{References}

Afrane, Samuel K; DeGraft Owusu-Manu; Kenneth Appiah Donkor-Hyiaman and Francis Kwesi Bondinuba (20|4). Towards Innovative Housing Financing in Ghana: An Evidence-Based From South Africa's Pension Housing Financing System, Public Policy and Administration Research ISSN 2225-0972(Online) Vol. 4, No.4,20I4 pp.97-II 0 Retrieved on $5 / 11 / 2016$

Amis, P. (1988).Commercialized Rental Housing in Nairobi, Kenya. In: C. Patton, ed., Spontaneous Shelter, International Perspectives and Prospects, $\left.\right|^{\text {st }}$ ed. Philadelphia: Temple University Press, pp.60-80.

Babbie, E. (1992). The Practice of Social Science Research, 6th ed., California: Wards Worth Publishing Company.

Blasi, A. (2005). Urban Housing Problems in Tanzania. Some Possible Policy Interventions. A Research Report.

Berry, L. Mascarenhas, O. and Steward, S. (1982).Eastern African Country Profiles, The United Republic of Tanzania. Massachusetts: Clark University Worcester.

Campbell, H. (1988). Tanzania and the World Bank's Urban Shelter Project: Ideology and International Finance.Review of African Political Economy, 42, pp. 6-8

Collier, P. and Anthony J. (20/3). Housing and Urbanization in Africa: unleashing a formal market process CSAE Working Paper WP/2013-0I, Department of Economics, Oxford University.

Dar es Salaam Region Socio-Economic Profile (2014), prepared by National Bureau of Statistics and Regional Commissioner's Office Dar es Salaam.

Ellis, F. (2006). Livelihoods Approach. In: Clark, A, ed., The Elgar Companion to Development Studies,Published by Edward Elgar Publishing Limited, UK, pp. 345-349.

Fox, S. (2013). The Political Economy of Slums: Theory and Evidence from Sub-Saharan Africa, Working paper Series 2013, I3-146.

Gilbert, A., Mabin, M. and Watson, V. (1997).Lowincome Rental Housing: Are South African Cities

Kulaba, S. (198I).Housing and Development, Occasional paper No. 2, presented to Centre for Housing Studies, Dar es Salaam, Tanzania.

Kyessi, A. (2008). Formalization of Unplanned Settlements and Its Implications On Poverty Reduction:The Case of Dar es Salaam City,
Different? Environment and Urbanization, 9(I), pp. I33-I 47.

Grimes, O. (1976) .Housing for Low-Income Urban Families, Economics and Policy in the Developing World. The World Bank, Washington D.C.

Hanai, Emmanuel E. and Chambi Alexander J. (2008). Environment and Social Mangement Framework for the Proposed Housing Finance Project. A Final Consultancy Report Submitted to the Bank of Tanzania, the United Republic of Tanzania.

Hoffman, M., Walker, C., Struyk, R. and K. Nelson (199I), Rental Housing in Urban Indonesia, Habitat International, I5(I/2), pp. I8I-206.

Kabyemera, L. (2000), Landlord and Tenant Relationship in Swahili Houses. Case study of Magomeni and Mburahati, Dar es Salaam,Bsc. Dissertation, University College of Lands and Architectural Studies.

Kaufmann, D.et al (2006). Globalization and Urban Performance. In: F.Leautier, ed.,Cities in Globalizing World. Governance, Performance \& Sustainability, The World Bank, Washington DC: pp.27-67

Kiduanga, J. (2015). Subsistence Mode of Urban Housing Provision in Tanzania: Analysis of Its Pattern and Challenges for Dar es Salaam Competitiveness, An article to be published as a Chapter in forthcoming Book Titled Dar es Salaam Competitiveness.

Kimm, P. (1977), Preparing a National Housing Policy, Agency for International Development, Washington D.C. A Research Report

Kissick D;,Leibson, D., Morey, K., Bachmann, J., Anderson, J. and Eckertl, J. (2006). Housing for All: Essential to Economic, Social and Civic Development. A report prepared in collaboration with the International Housing Coalition for the World Urban Forum III Vancouver.

Kiunsi, R. (20/3). The constraints on climate change adaptation in a with large development deficit: The case of Dar es Salaam, Environment \&Urbanization, 25(2), pp. 32I-337.

Kool,M., Verboom, D. and Linden, J. (1989). Squatter Settlement Improvement and Displacement. mA Review of Concepts, Theory and Comparative Evidence,Habitat International, I3(3) pp. I87-I 99.

Krantz, L.(200I). The Sustainable Livelihood Approach to Poverty Reduction, SIDA, Division for Policy and Socio-Economic analysis.

Tanzania Journal of Development Studies, 8(2) pp. I-22.

Lorna, M. and Robert, M. (2007). Principles and Processes for Enhancing Sustainable Rural Livelihoods: Collaborative learning in Uganda, International Journal of Sustainable Development \&World Ecology, I 4 pp. 604-6I 7. 
Mahanga, M. (2002).Urban Housing and Poverty Alleviation in Tanzania, Dar es Salaam: University Press LTD.

Majale, M. (2003). An Integrated Approach to Urban Housing Development: Has A Case Been Made?, Global Urban Research Unit, School of Architecture, Planning and Landscape, University of Newcastle. NEI 7RU.

Makalle, Albinus M; Simeon Mesaki and Victor, Martern A. (2009) Livelihood Opportunities through Informal Housing in the New Capital City of Dodoma, Tanzania, A Research Report

Mlawa, N. (20/5). The Practice and Challenges of Tax Revenue Collection From Rental Housing Sector in Urban Tanzania: A Case Study of Arusha City, Masters Dissertation, University of Dar es Salaam.

Materu, J. (|99|). Housing Provision for Low-Income Groups in Tanzania. In Tibaijuka, Anna K.., ed., Social Services Crisis of the 1990s: Strategies for Sustainable Systems in Tanzania, England, Ashgate Publishing Limited, pp 227-24I

Mlozi, M. (1997). Urban Agriculture: Ethnicity, Cattle Raising and Some Environmental Implications in the City of Dar es Salaam, Tanzania, African Studies Review, 40(3) pp. I-28.

Mutero, J. (20I0). Overview of the housing finance sector in Tanzania, No. I0, A Research Report No. I0 TANZANIA. Commissioned by the FinMark Trust
Mutero, J. (|98|).The Housing Policy: Options for Namibia, A report prepared for the United Nations Institute for Namibia.

Panel, J. (1975). The Urban World, New York: Mc GrawHill, Book Company.

Prime Minister's Office, Regional Administration and Local Government (PMO-RALG)(20I I)

Urban Development and management Policy, Final Draft, Dar es Salaam.

Scoones, I.(1998), Sustainable Rural Livelihoods. A framework for Analysis, IDS Working Paper 72.

Sheuya, S. (2004). Housing Transformations and Urban Livelihoods in Informal Settlements. The Case of Dar es Salaam, SPRING Centre, University of Dortmund, Research Series No. 45; 2004.

UNCHS (1993). Support Measures to Promote Rental Housing for Low-Income Groups, Nairobi.

UN- Habitat (2005). Indigenous Peoples' right to Adequate Housing. A global Overview, United Nations Housing Rights Programme Report No. 7, Nairobi.

UN-Habitat (20I0) Informal Settlements and Finance in Dar es Salaam, Tanzania, Nairobi, ISO | 400|:2004.

United Republic of Tanzania (URT).(2014).Basic Demographic and Socio-Economic Profile Report,Tanzania Mainland Bureau of Statistic, Ministry of Finance, Dar es Salaam .

World Bank AFTU I\&2 (2002) Upgrading Low Income Urban Settlements. Country Assessment Report, Tanzania. 